Home » Publications » E-seminars in history

View Edit Outline Access control Export

\title{
The Role of the Individual in Educational Reform
}

Richard Aldrich, Institute of Education, University of London

(This paper is not to be quoted or cited)

\section{Summary}

This paper is divided into four parts. It begins with an introduction which identifies key themes in respect of the two elements of educational reform and the role of the individual. The second and third sections provide quantitative and qualitative analyses taken from four recent studies of educational reformers. Finally conclusions are drawn in respect of universality, continuity, competition and change, historical construction and consumers of education.

\section{Introduction}

This paper has a thousand starting points, or to be more accurate, 993. That is the number of subjects contained in two biographical dictionaries of educationists: the first British; the second North American and European (Aldrich and Gordon, 1989; Gordon and Aldrich, 1997). These volumes provide short biographical and bibliographical entries in respect of 465 and 528 subjects respectively, all deceased, the vast majority of whom lived and worked during the last two hundred years. They are intended as works of reference, and insofar as the information contained therein is taken from secondary rather than from primary sources represent established - even traditional -patterns of selection and scholarship. But though the volumes and their brief entries may appear prosaic in the extreme, the experience of more then ten years of researching the lives of these men and women has been one of great challenge, excitement and inspiration. This paper has two large, and in some senses naive and over-ambitious purposes. The first is to attempt to convey some sense of that challenge, excitement and inspiration. The second to suggest that it is possible to draw upon these studies, and others, to re- visit the role of the individual in educational reform from an international perspective.

At this point two basic acknowledgments must be made. The first is that although the aspirations of this paper are international, its antecedents and assumptions, in common with those of its author, are essentially western European. The second is that the re-visitation contained herein is neither particularly novel, nor particularly profound. As Harold Silver has shown, the theme of 'Where have all the people gone?', with which Barbara Finkelstein began her presidential address to the American Educational Studies Association in 1982 (Silver, 1986, 300), was raised both in the United States and in the United Kingdom from the 1970s (Silver, 1983, 1734), and included a search for real people engaged at every stage of the educational process. With respect to profundity, although at first sight reference books of this type may appear to be less subject to the type of theorizing about history to be found in the works of such writers as Dominick La Capra, Hans Kellner and Haydn White which Sol Cohen has sought, somewhat unavailingly, to apply to studies in educational history (Cohen, 1991, 131-141), that is not necessarily the case. Though biographical dictionaries may raise fewer questions about literary and rhetorical devices than more narrative works, any major selection and presentation of subjects impinges heavily upon issues concerning history as a mode of construction and emplotment. Other important theoretical issues which are not considered here in any depth include those with arise from Marxist interpretations in which the role of the individual is minimized or even negated. In a paper of this length it is difficult to do more than acknowledge such dimensions. The remainder of this introduction is devoted to providing brief developments of the themes of educational reform and of the role of the individual in education.

Educational reform has been a central theme in history of education. 'Educational' (following Richard Peters) may be defined as pertaining to initiation into worthwhile activities; 'reform' as deliberately induced change for the better. Of course concepts of 'worthwhile' and 'better' are not, and have not, been universally agreed, not even within a particular group or nation. Nevertheless, two assumptions are made at this point. The first is that some values and conditions are widely, if not universally, approved: knowledge as opposed to ignorance; respect for others as opposed to disrespect; physical well-being as opposed to ill- health; personal well-being as opposed to despair; material well- being as opposed to destitution. The second is that education, and educational reformers, are concerned to promote such values and conditions.

Educational reformers do not exist in a vacuum. Whether as individuals or as groups their work is located within a variety of social, economic, political and administrative contexts. One of the most obvious features of twentiethcentury history has been the rise of the schooled society. At the end of the twentieth century, some states like Brazil, through the work of such reformers as Darcy Ribeiro, still strive to bring universal schooling to their people. In other countries, where universal schooling dates from the nineteenth century, there is a renewed emphasis upon increasing the efficiency of school systems -particularly with reference to securing success in an increasingly competitive global economy. Many historical and contemporary educational reforms may be located within this broad explanatory frame. Thus, for example, in England the major Education acts of 1870, 1902 and 1944 were fundamentally aimed at the provision of universal elementary (subsequently primary) and secondary schooling. In contrast, the prime purpose of the Education Reform Act of 1988 was not so much to increase the supply of education as to ensure the efficiency and cost-effectiveness of that which already existed. This was to be accomplished by the establishment of a national curriculum and national testing under the direct control of central government, by the abolition of the Inner London Education Authority on the grounds of its perceived extravagance, inefficiency and radicalism, and by a severe reduction in the powers of other Local Education Authorities. In November 1995 the newlycreated Department for Education and Employment - a merger of two previously distinct ministries - declared that:

The Government's principal aim for the education service at all levels and in all forms of learning is:

To support economic growth and improve the nation's competitiveness and quality of life by raising standards of educational achievement and skill and by promoting an efficient and flexible labour market.

(DfEE, 1995)

One recent comparative analysis of the historical relationship between the rise of the schooled society and the state in England, France and the USA has been provided by Andy Green in Education and State Formation (Green, 1990). Green, who is currently extending his analysis to include twentieth-century developments in countries of the Far East - notably J apan, Singapore and Taiwan - attributes differences between national education systems to varying trajectories in the creation of national states. Other interpretations of the schooled society include those of the human capital variety, which suggest that the interests of the state, and of the individual, are both best served by investment in education, and those which see universal schooling essentially as a means of 
al control. One recent collection of essays provides a combination of these approaches by arguing that in the countries of subSaharan Africa there is a need Icorporate appropriate personality characteristics in the education and training of the labour force (Adjibolosoo, 1995).

Although in most contemporary societies children and young people are initiated into the acquisition of such properties and qualities as knowledge, respect for others, and physical well-being in formal school systems, such systems are neither necessarily the most important source of education nor the most effective. Throughout human history the main site of education has been the family, frequently complemented by the workplace and the place of worship. One important new educational dimension of the late twentieth century is that of television, a medium which has considerable capacity not only for education but also for mis-education. For example, it has been reported that the average American child sees 8,000 killings and 100,000 other acts of violence on film and television by the age of 12 (Neill, 1996)

There is an extensive literature on educational reform - both historical and contemporary. Recent comparative studies of English-speaking countries include those edited by Carter and O'Neill (1995), while a forthcoming volume on the History of Educational Reform in International Perspective (Beauchamp, 1997) draws upon case studies in such diverse countries as Argentina, China, England, Germany, J apan, South Africa, Sweden and the USA. General studies of educational reform, however, including those of a comparative nature, tend to minimize the roles of individuals.

Biographical and autobiographical studies have been a major means of bringing individuals into history, including the history of education, but the process has not been unproblematic. It has been suggested that biography differs from history in that the one has a definite ending while the other does not, yet truly definitive biographies are few and far between, and the lives of subjects and the significance of their work, in common with other historical events, may be reinterpreted again and again in the light of new evidence or new perspectives. For example, Frank Smith's study of J ames Kay-Shuttleworth, the traditional 'hero' of English education, which had held the stage since 1923 (Smith, 1923), has recently been completely overturned by what now seems to be another incomparable study, by R.J.W. Selleck (Selleck, 1994).

Within the western European tradition the hagiographical approach, exemplified in the medieval period in lives of the saints, gave way at the time of the Renaissance to a reappraisal of the relationship between truth and fiction in biographical studies. Of course sanitized, if not saintly, biographies have continued to be produced from that day to this, although in the second half of the twentieth century the demands of some publishers, and readers, have led to a concentration upon sinning rather than upon saintliness, while sanitization has been replaced by dishing the dirt.

Individuals, however, come not only singly but in groups, and official biographical collections exist in several countries. In the United Kingdom, for example, a completely new edition of the multi-volume Dictionary of National Biography, which originated in the late nineteenth century, and was thereafter updated by decennial additions, is now being produced. Two significant areas of inclusion in this new version will be much larger numbers of women, and of teachers. Single-volume biographical dictionaries abound. Those in English include national collections - Archie Brown (ed.), The Soviet Union. A Biographical Dictionary (London, 1990), J ohn A. Garraty (ed.), Encyclopedia of American Biography (New York, 1974), Ernst Kay (ed.), Dictionary of Scandinavian Biography (London, 1976) and international compilations such as the Chambers Biographical Dictionary (Edinburgh, 1990) and the Macmillan Dictionary of Biography (London, 1981).

Older specialist educational works include P. Monroe (ed.), A Cyclopaedia of Education (5 vols, New York, 1911- 13), J .E. Roscoe, The Dictionary of Educationists (London, 1914) and Foster Watson (ed.), The Encyclopaedia and Dictionary of Education (4 vols, London, 1921-2). More recent studies are represented by J ohn F. Ohles (ed.), Biographical Dictionary of American Educators (3 vols, Westport, Conn., 1978), L. Glenn Smith and J oan K. Smith et al, Lives in Education. A Narrative of People and Ideas (New York, 1993) and the four-volume Prospects collection (Paris, 1993-4). There is an International Society of Educational Biography and an international journal, Vitae Scholasticae: The Bulletin of Educational Biography, published by Caddo Gap Press. In 1980 the UK History of Education Society produced an occasional publication, Biography and Education: Some Eighteenth- and Nineteenth-Century Studies (Leicester, 1980), while its Annual Conference of 1990, 'Biographical and Autobiographical Approaches to the History of Education', attracted papers from Denmark, the Netherlands, New Zealand and the USA. J oan K. Smith, who was president of the International Society of Educational Biography in 1987, reported on methodological and other issues in respect of educational biography in 'Biography as an Educational History Form in Research and Teaching' in Kadriya Salimova and Erwin V. J ohanningmeier (eds), Why Should We Teach History of Education? (Moscow, 1993). The Society's annual conference, held in Chicago in April 1996, suggested the following possible topics to intending presenters: ethical issues in life-writing, the role of biography in educational history, oral history, use of life narratives in the classroom, narrative research, experimental approaches to lifewriting, listening to silent voices, examining 'invisible' lives, feminist approaches to life-writing.

Historical studies which move beyond the contribution of an individual to groups of reformers include those by Peter Gordon and J ohn White, Philosophers as Educational Reformers (London, 1979), J ean Houssaye et al, Quinze Pédagogues. Leur influence aujourd'hui (Paris, 1994), and an important recent article in Paedagogica Historica entitled 'Break and Continuity: Observations on the Modernization Effects and Traditionalization in International Reform Pedagogy' by J ürgen Oelkers (Paedagogica Historica XXXI 3, 1995).

\section{Facts and Figures}

Which individuals have been chosen to represent the several elements of educational reform, particularly during the era of the rise of the schooled society? This section provides some facts and figures from four recent studies.

The first of these is the Prospects collection of 100 Thinkers on Education (4 vols, Paris 1993-4). Coverage is global, with a time span of some 2,500 years - from Confucius to the present day. Indeed, it is claimed that the work is the first systematic attempt to present, in three widely used languages, a comprehensive and first-hand view of the thought of the great educators, of every age and culture. ' (Morsy, XXIII 1/2, 1993, 12). Nevertheless, at least two thirds of the entries are European, with 11 from France, and a further eight apiece from Germany and the United Kingdom.

The second collection, by L. Glenn Smith, J oan K.Smith et al, entitled Lives in Education. A Narrative of People and Ideas (New York, 1993), covers 73 subjects. In this volume

The history of Western education is told through the biographies of individuals, past and present, who exemplify the education of their times or have made important contributions to the developments of educational theory or practice.

The two final volumes are thoseby Aldrich and Gordon to which reference has already been made: the Dictionary of British Educationists (London, 1989) and the forthcoming Biographical Dictionary of North American and European Educationists (London, 1997).

Data in table 1 is taken from the first two collections and indicates the centuries in which these subjects were born:

Table 1. Subjects by centuries of birth 
The Role of the Individual in Educational Reform by Richard Aldrich | Institute of Historical Research

\begin{tabular}{|c|c|c|c|c|c|c|c|c|}
\hline & 500 & 400 & 300 & 200 & 100 & OBC & OAD & 100 \\
\hline - & 1 & 1 & 2 & - & - & - & - & - \\
\hline 1 & - & 3 & 1 & - & 1 & - & 1 & - \\
\hline 200 & 300 & 400 & 500 & 600 & 700 & 800 & 900 & 1000 \\
\hline - & - & - & - & - & - & 1 & 2 & 1 \\
\hline - & 2 & 3 & - & - & 2 & - & - & 2 \\
\hline 1100 & 1200 & 1300 & 1400 & 1500 & 1600 & 1700 & 1800 & 1900 \\
\hline - & - & 1 & 3 & 2 & 2 & 16 & 58 & 8 \\
\hline 2 & 1 & 4 & 7 & 1 & 3 & 13 & 18 & 8 \\
\hline
\end{tabular}

Table 1 shows that both collections are heavily weighted towards the modern period. This is particularly true of the Prospects selection.

Table 2 presents a further breakdown of those born in the eighteenth, nineteenth and twentieth centuries across the four volumes. All subjects in the Dictionary of British Educationists and all but one in the Biographical Dictionary of North American and European Educationists were born in this period. One interesting feature, although admittedly the Aldrich and Gordon volumes begin with the 'modern' period and exclude living educationists, is the distribution across centuries. Some 184 subjects were born in the eighteenth century, 871 in the nineteenth and only 60 in the twentieth. Even the two volumes which include extant educationists contain 29 subjects born in the eighteenth century and only 18 from the twentieth.

Table 2. Subjects by decades of birth, 1700-1969

\begin{tabular}{|c|c|c|c|c|c|c|c|c|}
\hline & & & & & & & \multicolumn{2}{|c|}{ Totals } \\
\hline Thinke & cation & & & & & & \multicolumn{2}{|c|}{84} \\
\hline Lives $\mathrm{i}$ & & & & & & & \multicolumn{2}{|c|}{39} \\
\hline British & ists & & & & & & \multicolumn{2}{|c|}{465} \\
\hline \multicolumn{7}{|c|}{ North American and European Educationists } & \multicolumn{2}{|c|}{527} \\
\hline 1700 & 1710 & 1720 & 1730 & 1740 & 1750 & 1760 & 1770 & 1780 \\
\hline- & 1 & 1 & 1 & 3 & - & 1 & 4 & 3 \\
\hline- & 1 & - & - & 2 & 2 & - & 1 & 3 \\
\hline- & - & - & 2 & 5 & 7 & 5 & 11 & 15 \\
\hline 2 & 3 & 3 & - & 14 & 5 & 10 & 19 & 10 \\
\hline 1790 & 1800 & 1810 & 1820 & 1830 & 1840 & 1850 & 1860 & 1870 \\
\hline 2 & 1 & 5 & 3 & 2 & 4 & 7 & 9 & 7 \\
\hline 4 & - & - & 2 & 3 & 3 & 2 & 2 & 2 \\
\hline 24 & 42 & 50 & 38 & 44 & 36 & 52 & 42 & 29 \\
\hline 20 & 21 & 33 & 39 & 44 & 33 & 55 & 65 & 59 \\
\hline 1880 & 1890 & 1900 & 1910 & 1920 & 1930 & 1940 & 1950 & 1960 \\
\hline 13 & 7 & 5 & 2 & 3 & - & - & - & - \\
\hline 2 & 2 & 1 & - & 6 & - & 1 & - & - \\
\hline 31 & 12 & 15 & 2 & 3 & - & - & - & - \\
\hline 47 & 23 & 13 & 7 & 2 & - & - & - & - \\
\hline
\end{tabular}

Another, and even more interesting, fact to emerge is that of distribution across the sexes.

Table 3. Subjects by sex

\begin{tabular}{lll}
\hline & Male & Female \\
\hline Thinkers on Education & 97 & 3 \\
\hline Lives in Education & 56 & 17 \\
\hline British Educationists & 410 & 55 \\
\hline North American and European Educationists & 370 & 158 \\
\hline
\end{tabular}

\section{Classification}

Though the grouping of individuals by such factors as sex, location and date presents few problems, classification in terms of role with particular reference to educational reform is more problematic.

All four volumes interpret their brief - whether Thinkers', 'Lives' or 'Educationists' - in a broad sense. Subjects are not confined to those whose lives were exclusively or even primarily devoted to education. In his introduction to the Prospects collection Zaghloul Morsy comments that:

philosophers. politicians, sociologists, scientists, theologians, novelists, historians, poets and essayists of every period and culture have had much to say on the subject of education...Examples? Kant, al-F_r_b_, Bello, Nyerere, Ibn Khaldun, Grundtvig, Tolstoy, Tagore, to name but a few. (Morsy, XXIII 1/2, 1993, 8)

As if to exemplify this point the first entry in Lives in Education is that of Sappho, while Aldrich and Gordon, in the briefest of introductions, simply declare that their volumes are 'representative of many of the different categories which can be subsumed under the term "educationists"'. 
ough, Morsy, in common with Aldrich and Gordon, arranges his subjects in alphabetical order, he nevertheless conjures at some length both with the issues of ir and of categorization.

Having rejected periodization as inappropriate for an international and transcultural collection, Morsy then acknowledges the possibility of

Other categorizations, classifying the thinkers according to the educative model on which their work is based... reformist, conservative, domesticating, liberating, directivist/non-directivist, secularizedhumanist, religious-authoritarian, Prussian, maieutic, abolitionist, libertarian, politico ideological, centred on culture or on pedagogy, centred on the teacher or on the pupil, on the rights of the child, on the authority of the adult, on the demands of society, democratic-republican, feudal, monarchist, Marxist-Leninist, etc. (Morsy, XXIII 1/2, 1993, 13)

In contrast, Lives in Education does embrace periodization, being divided into 12 chronological chapters with between five and eight educators for each. The first six chapters progress from Greeks and Romans through Monastics and Humanists to the Reformers and the Enlightenment; the latter six are focused on Americans and particularly upon the USA. Of these the final three are concerned with The Outsiders', as represented by women, Native Americans and Hispanic Americans; The Critics' who include such names as Montessori, Maritain and Counts; The Paradigm Shifters', from Kuhn through Freire to Malcolm X.

Classification of the subjects contained in the second of the Aldrich and Gordon volumes is currently being undertaken. Analysis of the Dictionary of British Educationists was carried out in a highly perceptive review by Phillip McCann (McCann, 1990, 165-6). Some 80 per cent of the entries were English, with Irish, Scots and Welsh distributed roughly in proportion to their populations. McCann placed some 15 per cent of the subjects in the aristocratic class, slightly more than 10 per cent in the plebeian or working class, with the great majority in the middle. More than half of the subjects, some 56 per cent, attended the universities of Oxford and Cambridge, with a further 15 per cent attending other universities, mainly London and those of Scotland. Similarly a majority attended public (37 per cent) or grammar ( 21 per cent) schools. Only a small minority were educated in elementary or other schools for the working classes.

Although, as McCann rightly suggests, this volume does not adequately represent all elements of education and educational reformers - for example there are few classroom teachers - it does reflect education as publicly perceived during the two centuries characterized by the rise of the schooled society. Some 55 per cent of the entries found a career within the sphere of educational administration. These included such wellknown figures as J ames Kay- Shuttleworth and Robert Morant from the nineteenth century, and Henry Morris and Alec Clegg from the twentieth. Politicians constituted another significant group of some 13 per cent. Prominent among these were W.E. Forster, A.J . Mundella, Arthur Balfour, H.A.L. Fisher and R.A. Butler, whose names are inextricably associated with the educational legislation of 1870, 1880, 1902, 1918 and 1944 respectively. Some 14 per cent spent their lives wholly or mainly within the classroom, while a further 14 per cent, in McCann's judgement, could be classed as educational theorists 'in the sense that their theories were influential in changing practice' (McCann, 1990, 165-6). Five of the eight British entries in the Prospects collection of Thinkers on Education J ohn Locke, Thomas More, A.S. Neill, Robert Owen, J oseph Priestley, Herbert Read, Michael Sadler and Herbert Spencer are included. More and Locke are from an earlier period, only Read is missing.

Two major conclusions can be indicated at this point. The first is that the Dictionary of British Educationists mirrors, albeit perhaps in distorted fashion, the dominance of British society and of the educational system constructed for the poor, by male, Protestant, Oxbridge- educated figures who had very little concern for educational theory and whose own studies were classical and humanistic rather than scientific or technical. Nevertheless, while the educational ideas and works of such theorists as J oseph Payne, Herbert Spencer and A.S. Neill might find more acceptance outside Britain than within, individual reformers did profoundly influence many dimensions of formal education and culture in an institutional sense, especially during the nineteenth and early twentieth centuries. Examples include

- Robert Baden-Powell (1857-1941), founder of the Boy Scout and Girl Guide movements;

- Henrietta Barnett (1851-1936), founder of the Children's Country Holidays Fund, the London Pupil Teachers' Association and co-founder of Toynbee Hall;

- Andrew Bell (1753-1832) and J oseph Lancaster (1778- 1838), founders of the monitorial school system;

- George Birkbeck (1776-1841), founder of the mechanics' institutes;

- Mary Carpenter (1807-77), founder of ragged and reformatory schools;

- Maria Grey (1816-1906), founder of the Women's Educational Union, Girls' Public Day School Company and Teachers' Training and Registration Society;

- Albert Mansbridge (1876-1952), founder of the Workers' Educational Association.

\section{Conclusion}

Five brief, and preliminary, conclusions may be drawn: in respect of universality, continuity, competition and change, historical construction and consumers of education.

Thinkers on Education, though published initially in three European languages (English, French and Spanish) and concerned predominantly with European subjects, nevertheless was justified principally in terms of its international dimensions and universality - 'all these thinkers always have something to offer, over and above particular values and cultures'. (Morsy, 12) This concern for universality is consistent with the contention in the first section of this paper that some values and conditions, and the reform of education to promote such ends, are widely approved.

A second and related issue is that of continuity. Lives in Education may be compared with the classic work of Robert Rusk whose Doctrines of the Great Educators (London, 1918) went through no fewer than four editions and 15 reprints between 1918 and 1972. Of the 14 subjects in Rusk's fourth edition, ten (Plato, Quintilian, Loyola, Comenius, Locke, Rousseau, Pestalozzi, Froebel, Dewey and Montessori) are included in the Smiths' collection. Montessori, the only woman in the 14 subjects in the Rusk volume and in the collection of 15 pedagogues edited by J ean Houssaye, is one of the three female subjects amongst the 100 Thinkers on Education .

But while there are universals and continuities, it is also possible to discern the effects of competing and changing contemporary concerns, both in choice of subjects and of reform priorities. In the Prospects collection concentration upon universals produces a 'galaxy' of educational thinkers and reformers of whom only three per cent are female, while a coverage of 26 centuries includes a continuous period of 11 centuries which produced no subjects at all. Tables 1 and 3 show that Smith and Smith, within the narrower parameters of 'Western' education, have a much stronger concern for a more equitable distribution both across centuries and across the sexes. Nine subjects are included for the 11 barren Prospects centuries, while the 17 female entries constitute some 23 per cent of the whole. This is substantially higher than the 12 per cent of female subjects in Aldrich and Gordon's British volume, but rather less than the 30 per cent of their North American and European collection. The considerable increase in the percentage of female subjects between these two latter volumes reflects several phenomena, three of which may be identified here. One is a firmer resolve by the authors to achieve a more equitable balance between the sexes in selected subjects; the second an enlarged emphasis upon the nonadministrative dimensions of educational reform; the third the greater availability of secondary material in respect of North American women as opposed to some other parts of the world, an availability exemplified by such publications as Notable American Women (4 vols, Cambridge Mass., 1971-80).

A fourth conclusion concerns the relationship between individualsand past, current and future educational reform. Historical studies such as those considered in this paper necessitate the recognition of at least three individuals in the process - the writer, the subject, and the reader. Rusk's volume retained its popularity over several decades because it was perceived to be the distillation of the best that had been thought and taught about education within Western culture. Its 
' title, Doctrines of the Great Educators, indicated a concern for cultural transmission, not least to prospective and practising teachers. Thinkers on :ation and Lives in Education, though conceived and presented in a less didactic manner, are similarly designed to transmit educational ideas, ideals and practice across the centuries. The two Aldrich and Gordon volumes, on the other hand, by their very nature invite a greater control and ownership by the reader.

Finally, it is important to draw attention to the relationship between the individual and educational reform in respect of a person's own education. The rise of formal educational systems at national and local levels has tended to limit the role of the individual as an educational reformer in terms of the production of education for others, a tendency reflected in the distribution across time of subjects in the four volumes examined here. Nevertheless, in spite of the proliferation of formal educational systems, the role of the educational consumer has recently received considerable emphasis - not least in the United Kingdom. Once formal education for all becomes the norm in any society, a greater interest may develop in the different ways in which individuals make use of that educational system than in the contributions of those who have structured and continue to restructure it. Current work by Ari Antikainen and his colleagues at the University of J oensuu in Finland, based on a research project entitled 'In Search of the Meaning of Education', shows how individuals have made, and continue to make, highly selective use of formal educational facilities in the construction of their own life patterns and identities (Antikainen et al, 1996). In this late modern or postmodernist world, each person has a history, and a potential role, as a reformer of education.

E-seminars index | back to the top

\section{Acknowledgements}

I acknowledge with gratitude the co-operation of my co- author in these two volumes, Peter Gordon; of my wife, Averil Aldrich, who has undertaken much of the statistical analysis for this paper; and of my colleague, David Crook, who has commented with his customary wisdom and eye for detail upon the several drafts.

\section{References}

Adjibolosoo, Sanyo B.-S.K. (1995) The Significance of the Human Factor in African Economic Development . Westport, Conn.: Praeger.

Aldrich, Richard and Gordon Peter (1989) Dictionary of British Educationists . London: Woburn.

Antikainen, Ari et al (1996) Living in a Learning Society. Life-Histories, Identities and Education . London: Falmer.

Beauchamp, Edward ed. (forthcoming 1997) History of Educational Reform in International Perspective . New York: Garland.

Carter, David S.G. and O'Neill, Marnie H. eds (1995) Case Studies in Educational Change . London: Falmer.

Carter, David S.G. and O'Neill, Marnie H. eds (1995)International Perspectives on Educational Reform and Policy Implementation . London: Falmer.

Cohen, Sol (1991) 'Representations of History', History of Education 202.

Department for Education and Employment (1995) The English Education System . London: DfEE.

Green, Andy (1990) Education and State Formation . London: Macmillan.

Gordon, Peter and Aldrich, Richard (forthcoming 1997) Biographical Dictionary of North American and European Educationists . London: Woburn.

McCann, Phillip(1990) Review of Dictionary of British Educationists, Historical Studies in Education/ Revue d'histoire de l'éducation 21.

Morsy, Z. et al (1993-4) Thinkers on Education', Prospects XXIII 1/2 - XXIV 3/4.

Neil, Andrew (1996) 'Shots straight to the heart of our sick society', The Sunday Times 17.3.1996.

Selleck, R.J.W. (1994) J ames Kay-Shuttleworth. J ourney of an Outsider . London: Woburn.

Silver, Harold (1983) Education as History . London: Methuen.

Silver, Harold (1986) 'Zeal as a historical process: the American view from the 1980s', History of Education 154.

Smith, Frank (1923) The Life and Work of Sir J ames Kay-Shuttleworth . London: J ohn Murray.

Smith, L. Glenn, Smith, J oan K. et al (1993) Lives in Education. A Narrative of People and Ideas. New York: St. Martin's Press.

E-seminars index | back to the top

Site Has Changed: False

Expire In: 3 days 6 hours

Cache Generated: 1.32 seconds

Flush Page

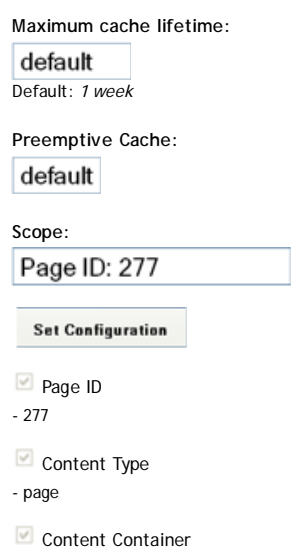

The Institute of Historical Research (IHR), Senate House, Malet Street, London WC1E 7H The IHR is a member of the School of Advanced Study which is part of the University of Londo 
The Role of the Individual in Educational Reform by Richard Aldrich | Institute of Historical Research

Uelete Configuration 